\title{
CORRESPONDENCE
}

\section{Indian Brain Drain}

SIR,-Out of nostalgia and loyalty I continue to read the Indian news sheet which the local Indian High Commissioner is kind enough to send me regularly. It appears that recently a new and successful export industry has arisen in frozen frogs' legs. Of course, nobody in India would ever consider eating frogs' legs, except perhaps in unavoidable circumstances, but they do go down well on gourmet tables in the West. But for this appreciation, the frogs would continue to rot in the swamps of India.

Now, Sir, may I commend the enterprise, and generosity of vision involved in this new industry, to the notice of those who worry about the brain drain from the developing countries: in particular, to $\mathrm{Dr}$ A. Parthasarathi (Nature, 230, 87; 1971). Just because a certain number of scientifically trained persons migrate and do well elsewhere does not prove that their countries could have used them professionally. By all accounts there is a large number of unemployed engineers and other technical personnel in India. Surely it could not be maintained that the laboratories in India were understaffed, or that scientists who are in that country have sufficient material support to be working at their most efficient. They could be overworked, certainly, but not in such activities that any increase in their numbers would improve the situation.

In any case, if in certain areas a need is felt, the governments could always arrange to have people specially trained in that area without setting up the kind of elaborate and generalized controls envisaged by $\mathrm{Dr}$ Parthasarathi.

The system of counsellors (advisers) and so on suggested in the latter part of his article has some curious echoes-of a certain mythical unshoulderable burden which still bothers the conscience of many a well-meaning white man (to their eternal credit, of course) and of mercenaries fighting against national movements. It is just as well that nothing is likely to come out of it, in view of the present administrative and intellectual turmoil in the universities throughout the West.

The main problem is to make the modern intellectual enterprise a relevant and self-sustaining force in these countries and the profitable and modish export which does no harm to this should be allowed to continue. Surely the countries of their origin have benefited because, for example, Chandrasekhar,
Khorana and Salam were able to use the opportunities they found in other countries.

$$
\begin{aligned}
& \text { Yours faithfully, } \\
& \text { KAILASH KUMAR }
\end{aligned}
$$

The Australian National University, Canberra

\section{Chemistry Teaching}

SIR,-Your recent editorial criticism ${ }^{1}$ of the report of the Committee of Enquiry which I chaired is seriously misleading because of the many errors of fact it contains, and I must ask for space to reply.

On the matter of broadening of courses you attribute to the committee opinions which it did not express and then criticize those opinions. Thus you point to our findings that some students would like to study a range of subjects outside chemistry and its essential ancillaries, and comment "The only puzzle is that the Eaborn Committee should dismiss the case for broader education without much concern for argument one way or the other". In fact, the clearly expressed view of the committee on this matter was that "It is highly desirable that chemistry students should have the option of spending some of their time outside chemistry and its essential ancillaries; this might be up to $20 \%$ of the three-year degree course in England and Wales. Our surveys reveal a substantial demand by students for courses in subjects such as economics and sociology, and we strongly favour such courses being available as options". You further note the wish of employers for inclusion in the course of commercial subjects (operational research, cost-accounting, marketing, industrial relations, computer programming, and so on), and state that "the committee takes the line that there is no time for luxuries like that". On the contrary, while we did, surely realistically, say that not all such subjects could be included in every chemistry course, we recommended that they should be available as options, saying in this context that "The differing inclinations of students can best be accommodated at present by setting aside time for a range of optional subjects other than chemistry and its essential ancillaries". Of computer programming, however, we stated unequivocally that "all chemistry students should receive instruction in this topic". Degrees in chemistry are already broader than those in some other sciences, since, except in one university, they involve courses in physics and mathematics, so that, with the same exception, the student spends between half and two-thirds of his time on chemistry as such. If our proposals for setting aside $20 \%$ of the time for optional subjects outside chemistry and its essential ancillaries were adopted, along with our recommendation that computer programming be included in all the courses, the students who wished to take up the options would spend no more than $40 \%$ $50 \%$ of their three years on the study of chemistry.

You also criticize the committee for disregarding the complaints of many chemistry students that too much factual material has to be remembered and that the work load is too heavy. On the contrary, we called on university teachers to examine the factual content of courses with a view to reducing it, and added "While emphasis on the memorizing of facts has decreased markedly in recent years, it is likely that this movement still has some way to go", furthermore commenting that "Provided that the graduate emerges with an adequate background of information and understanding, the attitude the course has induced in him is much more important than his detailed knowledge". We also expressed the view that the heavy work-load in chemistry prevents many students from reaping the full intellectual benefits of the university environment, and called on teachers to "consider carefully whether the work load in chemistry cannot be significantly reduced without serious loss of coverage", pointing to ways in which cuts could be made. We furthermore recommended that the time spent in laboratory classes should be reduced to the minimum necessary to meet a limited aim which we defined.

I will not attempt to deal with all the remaining inaccuracies in your account, but make brief comments on only three of them, as follows: (i) There is no justification for your statement that the committee, after pointing out some advantages of the present courses, "deplores the way in which students appear to be increasingly unwilling to exploit these advantages". On the contrary, we drew attention to the students' viewpoints, and commented "Univensity chemistry teachers must take account of the changing undergraduate attitudes, and ensure that their courses are in every way as attractive as possible to good students, 
rather than seek to maintain established practices simply because they may seem to be correct from the narrowest viewpoint of immediate vocational training".

(ii) It is more difficult to counter your statement that the committee "bemoans the difficulties which beset chemistry graduates seeking jobs", because it is entirely fiction, and I can only challenge you to produce quotations from the report in support of your assertion. In the matter of job shortages you may have been misled by your Education Correspondent's statement (not taken from the report) that "chemistry graduates have consistently formed the largest proportion of unemployed scientists six months after graduation" 2 . This is, in fact, the case (and not surprisingly so, since there are more graduates in chemistry than in any other science), but surely much more significant is the fact that in 1968 and 1969 , the latest years for which official (UGC) figures are available, the percentage of chemists still unemployed six months after graduation was below the average for all science students, and in 1969 , for example, the figure, $3.7 \%$, was less than half of that in zoology $(8.0 \%)$ or combined and general biological sciences $(8.3 \%)$.

(iii) You write that we "respond to the general feeling among chemists (in industry) and employers that a capacity to write literate reports would be an asset" by "woodenly proclaiming that we cannot recommend that a formal course in report writing and the use of English should form part of all chemistry degree courses", and you add that we "pass the buck downwards to the secondary schools and upwards to induction training". We were not, contrary to your assertion, responding to an opinion that capacity to write literate reports would be an asset, which no one could possibly question, but to the view that instruction in report writing and use of English should be included in all courses, and as far as buckpassing is concerned you carefully omit our comments that "the student's ability to write clear and correct English must be laid in the secondary schools, though university chemistry teachers can help the student build on these foundations", and "University teachers of chemistry should give thought to informal means of improving a student's ability to present a clear report", which we followed up by practical suggestions.

I hold the opinion, with you, that chemistry courses must be made more attractive to good students. But I cannot, as you do, condemn the present courses because $26 \%$ of the undergraduates disagreed with the statement that the present courses are "modern, lively, and up to date", since, given the spread of student inclinations and abilities, I think it likely that almost any course in any subject will be found deficient by this sort of proportion. Furthermore, while I, along with the rest of the committee, am strongly in favour of the broadening of chemistry courses along the lines indicated above, I am not aware of any justification for the view that making chemistry courses much more general will in itself greatly improve their attractions, and it is noteworthy that only $14 \%$ of the chemistry undergraduates surveyed considered that their courses involved too much specialization, while $21 \%$ considered that they involved too little. Something much more imaginative is needed, and at least one radically novel approach to undergraduate chemistry teaching has already been introduced in the light of the information presented by the committee ${ }^{3,4}$.

A final point. Chemists, whom you condemn for their conservatism, should at least be given credit for commissioning and publishing a thorough sociological survey of the attitudes of chemists and chemistry students. There is not the slightest reason to believe that the deficiencies and dissatisfactions it reveals are confined to chemistry and, indeed, the Docksey Report gives a clear indication that some of them are not. Non-chemists who seek to use the information in our report to attack chemists and chemistry courses might do well first to carry out similar surveys within their own disciplines to find out just how far their own houses are in order.

$$
\begin{aligned}
& \text { Yours faithfully, } \\
& \text { C. EABORN }
\end{aligned}
$$

School of Molecular Sciences,

University of Sussex, Brighton BN19QJ,

Sussex

1 Nature, 228, 1242 (1970).

2 Nature, 228, 1244 (1970).

3 Chemistry in Britain, 6, 330 (1970).

4 Nature, 228, 649 (1970).

REgRETTABLY this letter, received early in January, has not been published before this for reasons connected with the postal strike and not through any fault of Professor Eaborn's.

The chief complaint of the leading article was that the committee had been complacent and that the report would have a conservative influence. Unfortunately the report is a quarry for quotations which support this view and which tend the other way. Thus the report says "We are not convinced by arguments in the Swann Report that graduates would be more useful to industry if they had studied a wider range of scientific subjects to a less advanced level than is customary now in the special degree. We do not accept that any possible gains would outweigh the loss of professional competence in the subject of specialization". The recommendations that there should be more options are introduced with the phrase "While there is no convincing case for broadening all chemistry degree courses . . .". It is good to have Professor Eaborn's assurance that the report is really a recipe for reform; the difficulty is the impression created in the report that reform could be accomplished without substantial change.

On the three specific points raised here: (i) This was a reference to the decline of recruitment to chemistry departments. The report says "This state of affairs is a matter for concern for the country in general ...". (ii) The committee says that "it is true that the student image of industry is in some respects inaccurate and is not wholly favourable, but there are no grounds for believing that this is a consequence of anything in the degree course...." (iii) Can the blind lead the blind, even informally?-Editor, Nature.

\section{Announcements}

\section{International Meetings}

May 4-5, Electrical Association for Women Conference, London (Electrical Association for Women, 25 Foubert's Place, London W1V 2AL).

May 8, Human Diseases in the Seventies, London (The Conference Secretary, Joint Biology Committee, 2 Bramley Mansions, Berrylands Road, Surbiton, Surrey).

May 18, Perspectives in Laboratory Animal Science, London (The Honorary Secretary, Laboratory Animals Science Association, c/o Canterbury Biological
Laboratories Ltd, 45 Sandwich Road, Ash, Canterbury, Kent).

May 24-27, New Trends in Educational Technology and Industrial Pedagogy, Knokke (Secretariat, Lamorinierestraat 236, B-2000 Antwerp, Belgium).

June 2, Presenting a Technical Lecture, London (Institute of Electrical and Electronics Engineers, 2. Savoy Hill, London WC2).

June 4, Two-phase Morphology of Block Copolymers, Colchester (Professor M. Gordon, Department of Chemistry, University of Essex, Wivenhoe Park, Colchester, Essex).

June 7-9, Evolution of Genetic Systems, Upton, LI (Harold H. Smith, Brookhaven
National Laboratories, Upton, New York 11973, USA).

June 28-July 2, World Energy Conference, Bucharest (The Secretary, British National Committee, World Energy Conference, 5 Bury Street, St James's, London SWI).

July 5 8, Shock Tubes, London (Symposium Secretary, Department of Aeronautics, Imperial College, Prince Consort Road, London SW7).

September 21-October 2, Methods of Prospecting for Uranium Minerals (NATO Advanced Study Institute), Imperial College London (6 day course of lectures) and Cornwall ( 2 days of field work) (Dr Michael Davis, UKAEA, 11 Charles II Street, London SW1). 